\title{
The role of project's initiatives focused on the reduction of environmental footprints during COVID-19: evidence from the United States firms
}

\author{
Mohamed M. Dhiaf ${ }^{1} \cdot$ Khakan Najaf $^{2} \cdot$ Hazem Marashdeh $^{3} \cdot$ Osama F. Atayah $^{3} \cdot$ Guilherme F. Frederico $^{4}(1)$
}

Received: 30 May 2021 / Revised: 11 July 2021 / Accepted: 23 July 2021 / Published online: 18 October 2021

(c) The Author(s), under exclusive licence to Springer Science+Business Media, LLC, part of Springer Nature 2021

\begin{abstract}
In this paper, we examine whether the projects of the United States (U.S.) corporations have implemented initiatives to reduce the environmental footprint of their supply chains during coronavirus (COVID-19). Environmental footprint reductions could be achieved by reducing waste, reducing resource use, and reducing ecological emissions by introducing environmental management systems in the supply chains. For this aim, the project's initiatives play a crucial role. This study has the primary purpose of examining the impact of ecological footprints on financial performance achieved by US corporations' initiatives implemented through projects during the COVID-19 period. The final sample comprises 9997 company-year observations over the investigation period between 2010 and 2020. The results suggest that firms implementing the initiatives to reduce environmental footprint have shown a significant positive financial performance during the COVID-19 period. The results are robust to alternative specifications of informativeness and sensitivity tests controlling for time-invariant firm characteristics and alternative firms' performance measures. Our results corroborate with stakeholder theory, which implies implementing green policies will alleviate the agency issue and safeguard the shareholders' interest. Moreover, it clearly demonstrates the positive impact of environmental projects-focused organizations on the financial and environmental performance even while challenging and disrupting situations such as this unprecedented pandemic.
\end{abstract}

Keywords COVID-19 $\cdot$ Environmental footprints $\cdot$ Supply chains $\cdot$ Financial performance $\cdot$ Stakeholder theory

\section{Introduction}

Guilherme F. Frederico

guilherme.frederico@ufpr.br

Mohamed M. Dhiaf

dhiafmohamed@yahoo.fr

Khakan Najaf

khakann@sunway.edu.my

Hazem Marashdeh

hmarashdeh@gmail.com

Osama F. Atayah

Dr.osamaatayah@gmail.com

1 Faculty of Business Administration, Emirates College of Technology - ECT, Abu Dhabi, UAE

2 Sunway University, Selangor, Malaysia

3 Abu Dhabi University, Abu Dhabi, UAE

4 Federal University of Paraná - UFPR - School of Management, Curitiba, Brazil
In the context of growing worldwide competition, technological changes, and an economic drop globally, long-term business sustainability has become imperative. Today, this implies integrating economic, environmental, and social supply chain issues into decision-making processes, which means that commitment to supply chain sustainability dimensions is perceived as key for the future business success of organizations. By introducing supply chain sustainability concepts into its business, an organization takes responsibility for its influence through different forms of actions, clients, employees, management, the community, surroundings, and the environment itself (Toljaga-Nikolić et al. 2020). Changes are usually introduced through projects, and the integration of sustainability and project management concepts contribute to genuine changes in thinking, operations, cooperation, and partnerships on different levels of business and organization (Silvius 2013). Many studies, such as (Zamojska and Próchniak 2017; 
Michaelides et al. 2014), stress that projects provide a positive economic benefit; however, all of these projects must be positively associated with environmental impacts. Their study indicated that corporation green project outcomes are the results of sustainable project management practices: Easier access to capital markets in the future, high customer loyalty, improvements in a supply chain, the development of capabilities, improvements in operational performance and efficiencies in the long term, positive organizational image and credibility, among other things.

Nevertheless, the effective and efficient management of the sustainable project processes requires a complex mix of different economic, societal, and environmental utilities, such as systems, structures, plans, resources, laws, regulations, and technologies. Moreover, it is necessary to ensure that sustainable project objectives are aligned with societal objectives (Michaelides et al. 2014). Sustainable supply chain project management is an accelerated roadmap to sustainable development. The way our future will look depends significantly on supply chain project managers since the challenges relating to sustainability are quite concrete and rely on the adequate planning and implementation of projects, which can guarantee the protection of world resources and, at the same time, create welfare for people (Silvius 2013). In summary, it implies that the integration of sustainability with supply chain management is the key to effective and efficient supply chain management.

Since the appearance of the coronavirus disease (COVID-19) in China in December 2019 has spread globally (Bowman and McKenzie 2020; Shen et al. 2020). The pandemic has provoked severe social and economic disruption globally, including strict social distancing, travel restrictions, and one of the most significant global recessions since the Great Depression (Kuckertz et al. 2020). During the beginning of the worldwide outbreak in March 2020, Supply Chain (SC) management has significant problems coping with an unpredicted demand for certain products when simultaneous restrictions for travel and production have been enforced (Alles and Gray 2020). Also, SCs concerning the pandemic are widely discussed, and scientific research on the implications of the crisis has already started (Queiroz et al. 2020; Schmidt 2020).

So far, the extant literature has discussed the negative impact of COVID-19 on the financial performance of the firms (Rababah et al. 2020; Shen et al. 2020; Song and Zhou 2020) and also how logistic firms outperformed the rest of the industrial sectors because of the high demand for supply chain technology during the pandemic period. However, traditional research paradigms fail to keep up with the pace of the current epidemic and economic developments. Thus, there is still little empirical evidence on how the COVID-19 impacts the performance of the firms which implement any initiative to reduce environmental footprints (EF) of their supply chain.

This issue is necessary to investigate because Modern sustainable supply chain management involves integrating environmentally and financially viable practices into the complete supply chain lifecycle, from product design and development to material selection (including raw material extraction or agricultural production), manufacturing, packaging, transportation, warehousing, distribution, consumption, return and disposal. Environmentally sustainable supply chain management and practices can assist organizations in not only reducing their total carbon footprint but also in optimizing their end-to-end operations to achieve greater cost savings and profitability. All supply chains can be optimized using sustainable practices. Sustainability in the supply chain encapsulates several different priorities: environmental stewardship, conservation of resources, carbon footprint reduction, financial savings and viability, social responsibility.

Therefore, in the present research, we are motivated to examine the U.S.'s financial performance of corporations that have implemented initiatives to reduce the Environmental Footprint (EF) of their supply chain during COVID19 and compare it with their counterparts. We assume this because the EF firms are anticipated to perform well during the pandemic period. We test this proposition and choose all U.S. firms which disclose the EF information. This process yields 1057 listed firms from the year 2010 until 2020. For the COVID-19 effect, we split the sample into two periods; first, we consider the year 2010 until 2019 as the pre-COVID period. Second, we flag the year 2020 as the during-COVID period. We use annual data for all the variables because financial performance does change frequently, but it evolves gradually over a year.

Firstly, the relationship between the interaction variable of COVID-19*EF and financial performance was evaluated to analyze how older coronavirus influenced financial performance. Secondly, the univariate tests, sub-industry analyses, robustness tests were examined to confirm our main findings. Using a sample of 9997 firm-year observations of U.S. listed firms for the period 2010-2020, the results show that the pandemic period negatively impacts financial performance. However, those firms which implement the EF policies/initiatives during the pandemic period their financial performance is significantly higher than the non-EF firms. The results are robust by the industry-wise analyses, sensitivity, and robustness tests. The findings of this study corroborate with the latest literature, which claims that there is a certain increase in financial performance for firms that implement EF policies (Andries and Stephan 2019; Neeveditah et al. 2017; Alipour et al. 2019; Zgheib et al. 2017).

The rest of the paper is organized as follows: the theoretical background and hypothesis development are presented 
in Sect. 2. Section 3 describes the sample characteristics, methodology, data collection, and findings of the empirical results. In Sect. 4, we conclude this study.

\section{Literature review and hypothesis development}

\subsection{Sustainability and project management}

The prior studies make an effort to examine the relationship between sustainability and project management in the last recent years. These studies provide an overview of how sustainability is considered in the context of project management (Edum-Fotwe and Price 2009; Martens and Carvalho 2016; Sánchez 2015). The integration of sustainability into project management practices is defined as the comprehensive and harmonized assimilation of social, economic, and environmental principles into effective project delivery systems (Banihashemi et al. 2017). Although the temporary nature of projects may contradict the concept of sustainability with its focus on the long-term horizon, usually projects occur in a broader environment than that of the projects themselves (Silvius et al. 2012). Therefore, projects are influenced by different internal and external factors.

These factors may have significant impacts on the outcomes of these projects (Dangelico and Nonino 2019). In addition to managing internal factors such as cost, schedule and scope, a project manager needs to consider the external factors of the economic, social and environment. Also, projects or deliverables of a project can have social, economic and environmental impacts that far outlast the projects themselves (Sánchez 2015). Sustainability integration in projects can be done either on the content of the project or the process or delivery of the project (Gareis et al. 2013). These two different perspectives of the sustainability integration in projects, either by the content of the project or by the process or delivery of the project, are a recurring theme in studies on project management and sustainability (Silvius 2017).

Several studies argue that projects and project managers play a crucial role in realizing sustainability in organizations and society. Some studies show that certain elements attain sustainable projects, such as project products designed using sustainability criteria, sustainable project processes, and project managers trained in sustainability (Marcelino-Sádaba et al. 2015). Other studies conclude that project managers fulfil the traditional roles of project management and manage the project most efficiently and effectively concerning sustainability (Hwang and Ng 2013). Similarly, Sánchez (2015) presents a theoretical framework to address the need to integrate sustainability in Project Management. The framework evaluates projects based on the profits and economic, environmental, and social impacts. Robichaud and Anantatmula
(2011) argue that greening project management practices can add significant value to a sustainable construction project while delivering it within acceptable cost constraints. Other studies went further and argued that the environmental aspects and economic goals are correlated to the behaviour of management and their managing style (Tingström et al. 2006; Valdes-Vasquez and Klotz 2013). Saeed Banihashemi et al. (2017) propose a set of critical success factors (CSFs) to integrate sustainability into project management practices on construction projects in developing countries. Silvius et al. (2017) investigate whether the dimensions of sustainability are considered in the decision-making processes of project managers concerning the triple constraint of time, cost, and quality. Their results reveal that the consideration of sustainability principles is underrepresented compared to the triple constraint criteria. In a recent study, Chofreh et al. (2019) emphasize that introducing sustainability into project management concepts and methods should support organizations in achieving a competitive advantage.

Drawing on the relationship between sustainability and project management, a large amount of literature has demonstrated that managing supply chains sustainably has become an increasing concern for all industries (Seuring 2013). It implies that industries need to meet the environmental standards along all stages of supply chains. Gimenez et al. (2012) argue that the term sustainability is used to include environmental management, the closed-loop supply chains and a broad perspective on the triple-bottom-line, which is considered as an accounting framework that evaluate the performance of firms based on three perspectives, including the social, environmental, and financial. Linton et al. (2007) argue that to enhance the convergence between supply chains and sustainability, the focus should be moved from local optimization of environmental factors to consideration of the entire supply chain during the production, consumption, customer service and post-disposal disposition of products. Therefore, the supply chains must be extended to include the product's entire life cycle and optimize the product from a current cost standpoint and from a total cost standpoint, which provides for both the implicit and explicit costs.

Following the same premises, Michaelides et al. (2014) emphasize that important project outcomes are the results of sustainable project management practices, and one of the most important practices is the improvements in a supply chain and operational performance, among other factors. Hussain et al. (2016) introduce a comprehensive framework for investigating and assessing sustainability across the supply chains in the service industry; they claim that the corporation not only acts in their interests but also protect the interests of stakeholders and society while managing and improving sustainability measures throughout the supply chains. 


\subsubsection{Theoretical background}

Resource orchestration theory (Wong et al. 2018) suggests a positive relationship between ecological implementing practices and value creation. It assumes that the management strategically enhances the competitive abilities, causing a higher firm's value (Freudenreich et al. 2020; Chernev and Blair 2015). In contrast, the trade-off theory implies that environmental practices lead to losing focus on its established firm plans, ending in weaker earnings. Additionally, the environmental management system (EMS) is positively associated with the firms' financial performance in the cases of well financially performing firms. At the same time, it has a severe negative implication on low-performing firms' financial performance (Wagner and Blom 2011).

Remarkably, various studies have found that many firms have received environmental awards and faced significant losses, indicating that market partners are not considering the environmental aspects in their investment decisions (Huynh 2020; Qiu et al. 2021). Consistent with the outcomes of Giuli and Kostovetsky (2012) study when they reported that the environment-protected projects represent an extra cost on the firm and are negatively related to the market and financial performance. Thus, trading off between the ecological projects' investment and the expected cost is recommended, which helps the firms' leaders manage and allocate the firm's resources efficiently, positively influencing the firms' financial efficiency (Ionescu et al. 2019; Kolsi and Attayah 2018).

\subsection{Sustainability and corporate performance}

The relationship between the firms' environmental performance on their financial position has been subject to debate, and the outcomes were inconsistent (Grougiou et al. 2014). There is substantial evidence of inconsistency in the literature regarding the impact of environmental performance or the ultimate impact of environmental performance on other factors (Perrini et al. 2016). The dominant part of studies demonstrates that the ecological activities achieve several benefits to the firm; satisfying several stakeholders' needs contributes to adding value to the firm's shareholders (Kuckertz et al. 2019; Panayiotopoulos 1996; Sharir and Lerner 2006).

One school of thought, accepting environmental protection practices improves the firm's reputation, financial performance, and competitive advantage. The association of firms' environmental performance and financial performance is justified and thoroughly presented in different sustainability theories, such as legitimacy, stakeholder, and agency theories. In this regard, Sroufe et al. (2019) documented that firms engaged with more environmental and sustainable initiatives are better positioned than counterparts in operational and financial risk. Building on their study, Najaf et al. (2021a, b, c) clarified that the firm's positive reputation builds a trustful and secure relationship with the stakeholders, lowering the possibility of firms facing litigations or adverse market reactions, leading to mitigating and reducing the firms' operational risk.

Accordingly, lowering the operation risk enhances the accessibility of firms to financial resources. It leads to a decrease in capital cost, leverages the firms' financial performance and market value (Semenova and Hassel 2013). However, Mejia-Escobar et al. (2020) also confirmed that a good reputation reduces operational risk, considering that the environmental relationship builds a loyal relationship with customers and offers respectful relationships with lenders and investors, enhancing firms' relationships ability to access financing. In addition, taking data of U.S. corporations, Eccles et al. (2014) documented that when the implication of environmental practices continues for a long-term period, the corporations gained advantages such as share prices and financial performance. Furthermore, Alsayegh et al. (2020) posited that the environmental protection practices leverage the firms' competitiveness and ability to assess the firm's role in social responsibility, including maintaining, protecting, and sustaining the environment and supporting the surrounding community.

Another school of thought debated the negative influence of environmental activities on firm financial performance. Their main argument stands on the extra cost allocated for environment investment, which exacerbates firms' financial income and firms' market value (Jensen 2002). Furthermore, based on the stakeholder theory, the firm's objective is to generate value for all shareholders (Freeman et al. 2010; Freeman and John McVea 1989). However, investing in environmental projects is opposite to the shareholders' interest, who presume to maximize their wealth (Dranev et al. 2020; Kolsi and Attayah 2018).

\subsection{COVID-19 and corporate performance}

Several studies have been conducted to examine and assess the COVID-19 implications on the firms' financial position (Al-Kharusi and Murthy 2020; Elnahass et al. 2021; Vogel 2020). For instance, the restaurants and tourism sector in the U.S. has faced financial difficulties, especially the liquidity and higher operational risks. Consistently, Zoğal et al. (2020) confirmed that the current pandemic has an adverse implication on the tourism industry, which witnesses negative financial impact and unfavourable changes in consumers' behaviour; the study anticipates a difference in the tourism behaviour toward second house tourism. Likewise, financial sectors' performance has decreased, with a decline in the loan demand and a significant increase in the operation and lending risk (Elnahass 
et al. 2021; Al-kharusi and Murthy 2020; Dwiarti et al. 2021; Rababah et al. 2020).

Nevertheless, the studies described the response techniques that have been implemented to override with minimum losses during the current pandemic; firms responded to the consequences in several ways-first cutting cost, which is still insufficient to grasp the economic consequences and negatively correlated to the operation sustainability (Czerny et al. 2021). Second, capital increases through credit arrangement and governmental support enable the firm to sustain itself (Polishchuk et al. 2020).

In summary, these inconsistent results and outcomes about the sustainability and environment practices and the firm's financial performance remain theoretically ambiguous, especially in uncertain economic situations such as the COVID-19 situation. Thus, investigating if the environmental practices and targeting to reduce environment footprints contributed to overriding or reducing the negative consequences of COVID-19 on firms' performance or not is essential to offer a deep understanding of this knowledge arena. Accordingly, we have developed our hypothesis as follows:

H1 Ceteris paribus, the firms with EF reduction policies yield better financial performance than their counterparts during the pandemic period.

\section{Method, sample, and data}

We empirically tested our hypothesis of financial performance comparison between the firms with environmental measures versus those firms without it during the pandemic period (year-2020). As per our knowledge, there is no study available that analysis these two distinct environmental implementation structures in the context of the COVID-19 period. Thus, in line with our central hypothesis, we tested the effect of environmental footprint (EF) with an interaction with COVID-19 on financial performance, which is the study's primary aim. In Appendix Table 7, we have summarized the test variables and discussed their relevance in this section. The empirical models are presented in the respective tables.

\subsection{Dependent variables}

Following the prior literature, we use Return On Assets (ROA), Return On Equity (ROE), and Earning Per Share (EPS), for the performance measurements (Najaf et al. 2021a, b, c). Whereas ROA, ROE, and EPS are considered proxies for the firms' financial performance.

\subsection{Independent variable}

Basically, we are looking for the difference in the firms' financial performance during the COVID-19 that implement the EF concept with that of without EF. To differential the EF firms from counterparts, we create a dummy variable, where the value of " 1 " is assigned to EF firms and " 0 " otherwise. The practice of assigning dummy variables to the two different groups within the dataset is not new. The seminal work of Najaf et al. (2020) allocated dichotomous values to the Fintech and non-Fintech firms.

Where " 1 " indicates, the company has implemented any initiatives to reduce the environmental footprint of its supply chain. Environmental footprint reductions could be achieved by reducing waste, reducing resource use, reducing environmental emissions, insisting on the introduction of environmental management systems in the supply chain. "0" indicates that the company has not explicitly disclosed any such efforts in its most recent Annual or Company Responsibility reports.

We check the impact of EF on the financial performance during the COVID-19 period. For this reason, we create a dummy variable (COVID), where the value of " 1 " is assigned to all observations during the year 2020 and " 0 " to the prior COVID-19 period (the year 2010 until 2019) (Najaf et al. 2021a, b, c). To check the impact of EF during the COVID-19, we considered the interaction between the COVID and EF variables.

\subsection{Firm-level controls}

Following the earlier studies and theory, we specify other variables in our regression analyses that control the observable firm-specific characteristics. We winsorize the firmlevel variables at $1 \%$ level in each tail of our sample distribution. The prior study posits a non-linear relationship between foreign ownership and EF reduction policies and a leading impact on performance (Ali et al. 2020). Similarly, we control government shareholding, where a firm has more than $1 \%$ of institutional shareholding (Najaf and Najaf 2021). Nevertheless, we control for the Bloomberg Industry Classification Systems (BICS) segments of a business group. The literature shows that market diversification causes agency problem and enhance the information asymmetry. Thus, the conglomerates' firms have weak governance leading to not applying EF reduction policies (Tosun 2020). The firm's Size was also controlled due to its direct correlation with $\mathrm{EF}$ reduction policies, which was prone to be lower in smaller-sized firms (Najaf et al. 2020). Seemingly, capital Ratio has a direct relationship between investment propensity and higher earnings volatility (Hassan and Giouvris 2019). Meanwhile, the Leverage was the ratio between the 
firms' total debt to total assets. The Leverage was controlled as it could increase EF reduction policies (Ali et al. 2020).

Naturally, as companies grow and develop, they generally become larger, always become older. Thus, EF reduction policies changes with the firm age (Dickinson 2011; Tran and Le 2020). Furthermore, cross-sections were constructed at the firm level as the dataset was a firm-specific panel dataset. As companies grow and develop, the companies generally became bigger and older; hence, EF reduction policies may change with the firm's Growth (Tran and Le 2020). Lastly, shareholders tended to perceive firms audited by the top-ranked audit firms as displaying better EF reduction policies (Hassan et al. 2020). Following the premises, the Big4 audit firms' variable was controlled because shareholders' perception of good governance could better influence EF reduction policies.

\subsection{Fixed effect control}

We use a sample that comprises the United States EF- and non-EF firms, which requires controlling for any unobserved time-variant effect by introducing year dummies. We control industry membership. Many factors potentially correlated with firm performance may cluster by industry. These factors include product market concentration (Ali et al. 2014) and degree of regulation (Ahmad and Hussain 2001). Industry membership is proxied by a series of dummies, corresponding to classifications by Bloomberg. The industry sectors are named accordingly to the Global Industry Classification Standard (GICS). We collected data for both GICS mainand sub-sectors. We include a total of ten dummies of 11 industries for ten years of data (Shin et al. 2018).

Also, we control for the yearly dummies because financial performance may vary temporally following changes in macroeconomic conditions (Dickinson 2011). For example, companies may be in abnormal loss during recessionary periods, irrespective of environmental footprint. We constructed nine dummies for ten years of data.

\subsection{Sample and data}

In this study, we gathered the data of all those U.S. listed firms that disclose the EF information as of 2020 year. We identify samples by reviewing the company EF indicates available at the Bloomberg database. We face challenges during the sample selection as there are various definitions for the EF firms, and different agencies identify EF quality differently.

It is worth noting that we flag EF firms based on the 2020 year, preferably any prior years. The adherence to the environmental footprint reduction became a part of the U.S. code of conduct during 2010 (Network 2020). After the official announcement, the U.S. firms voluntarily adopts the EF in subsequent years. Later, we select the matching sample for our flagged EF firms. In this study, we compare two distinct types of reporting firms. One is the EF firms that implement the environmental footprint reduction policies, and the second is the non-EF firms. Overall, combining both the EF and non-EF firms, our study sample comprises a total of 1057 U.S. listed firms.

We gathered the data from 2010 until 2020 as the research sample to examine the COVID*EF impact on financial performance. The pre-financial crisis data (2008-2009) were not included to create a financial performance bias. This screening process yields us 565 firms with a total number of observations are 9997 (Year-firm). Table 1 represents the sector-wise and year-wise distribution of the data.

Panel A demonstrates the number of firms implementing the environment footprint (EF) reduction policy. The second column shows the total number of firms reporting EF regardless of these firms implementing (or not) environmental measures. Eleven U.S. sectors documented the EF firms, and among these sectors, Information Technology had the highest, and Real estate had the lowest number of firms that implement EF. Moreover, Panel B demonstrates the year-wise and sector-wise EF. It should be noted that the EF increased from 33 to 174 years during this study, demonstrating that over time, the firms preferred to implement the EF policies. At the same time, the Information Technology sector's management implements the EF policies, on average, $23.09 \%$ of firms. In contrast, Real estate has the lowest percent of $0.36 \%$ of implementing the EF measure. This observation is helpful for investors who are inclined to invest in the implementation of the EF measures.

Based on the descriptive statistics in Table 2, the dependent variables ROA varied from 0.115 to 505.11 with an average of 14.14 and a standard deviation of 79.46. The firm's level control variables' distribution was slightly skewed to the positive side from the symmetrical position with mostly platykurtic peaks. Similarly, we found the same for ROE and EPS. In addition, the distributions of ROA were skewed toward the right side and were leptokurtic. Meanwhile, both ROE and EPS distributions were skewed toward the left and were leptokurtic, indicating outliers.

There were significant variations of the data observations with skewed distributions and leptokurtic or platykurtic peaks, as presented by the descriptive analysis. The results were representative of the real-life situation. Kurtosis is a statistical measure that defines how heavily the tails of distribution differ from the tails of a normal distribution. In other words, kurtosis identifies whether the tails of a given distribution contain extreme values. Table 2 reveals that almost all study variables are leptokurtic, meaning that the values of those variables are broader or flatter in shape with fatter tails resulting in a greater chance of extreme positive or negative events. These observations are typical of the real-life 


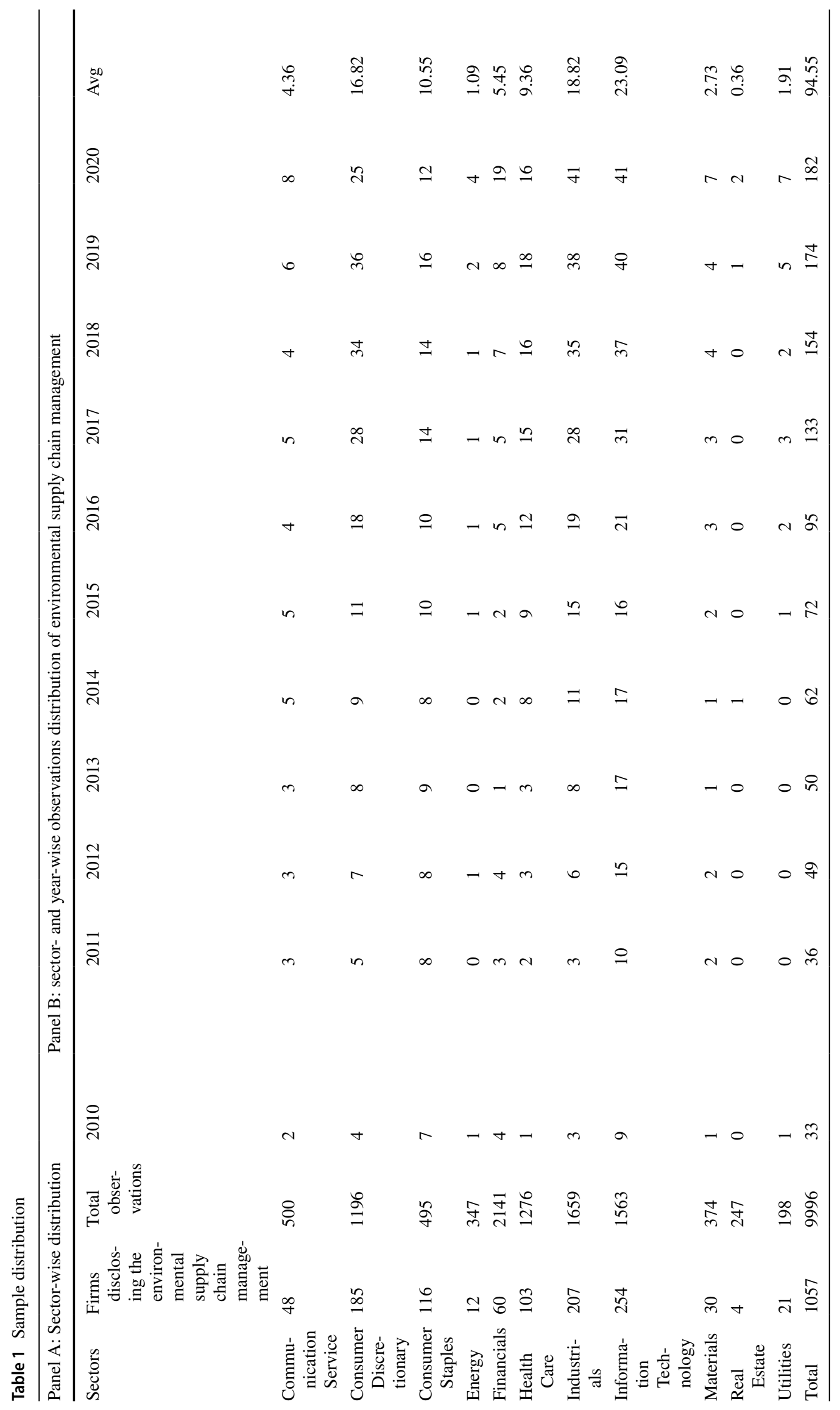


Table 2 Variable descriptive statistics

\begin{tabular}{|c|c|c|c|c|c|c|c|c|c|}
\hline Variables & Obs & Mean & Std.Dev & Min & Max & $\mathrm{p} 1$ & p99 & Skew & Kurt \\
\hline$R O A$ & 9572 & 14.14 & 79.863 & .115 & 505.11 & .623 & 12.576 & 67.814 & 41.12 \\
\hline$R O E$ & 9120 & 1.712 & 35.115 & -185.37 & 79.46 & -185.38 & 79.46 & -2.81 & 14.49 \\
\hline$E P S$ & 9662 & 1.142 & 4.162 & -19.93 & 20 & -19.93 & 20 & -.291 & 15.046 \\
\hline Foreign Shareholding & 9996 & .003 & .054 & 0 & 1 & 0 & 0 & 18.485 & 342.69 \\
\hline Government Shareholding & 9996 & .003 & .058 & 0 & 1 & 0 & 0 & 17.059 & 292.03 \\
\hline BICS Segment & 9996 & 1.636 & 1.241 & 0 & 11 & 0 & 6 & 1.913 & 8.991 \\
\hline Size & 9673 & 5.875 & 2.19 & -1.061 & 11.08 & -1.061 & 11.08 & -.433 & 3.624 \\
\hline Capital Ratio & 9362 & 3.703 & 5.255 & .02 & 32.55 & .02 & 32.55 & 3.121 & 14.893 \\
\hline Leverage & 9986 & 22.63 & 25.302 & 0 & 137.06 & 0 & 137.065 & 1.804 & 7.177 \\
\hline Age & 9996 & 43.345 & 31.706 & 0 & 87 & 0 & 87 & -.082 & 1.255 \\
\hline Growth & 9269 & 14.741 & 67.384 & -1 & 561.13 & -1 & 561.13 & 6.80 & 51.86 \\
\hline Big4 & 9833 & .511 & .5 & 0 & 1 & 0 & 1 & -.045 & 1.002 \\
\hline
\end{tabular}

The definitions of above variables are available in the Appendix Table 7

situation. Therefore, the data observations were winsorized at the $1 \%$ level on both sides of the distributions and relied on the robust t-values to test the statistical significance of the model coefficients' estimates.

\section{Empirical findings and discussions}

\subsection{Univariate tests}

Table 3 provides correlations statistics (two-tailed test), including both Pearson and Spearman-rank correlations for the studied variables. Both Pearson and Spearman-rank correlation shows the similarity between $E F$ and the three dependent variables (ROA, ROE, and EPS). Hence, the correlation between $R O A$ and $E F$ is 0.034 (Pearson correlation) and 0.2018 (Spearnmank-rank) with a $95 \%$ confidence interval, respectively, delivering the rudimentary support for the positive prevalence nexus between $R O A$ and reduction of ecological footprint. Also, the correlation coefficient for $R O E$ and $E F$ is 0.149 (Pearson) and 0.2549 (Spearnmankrank) at the 0.05 level of significance, implying the positive association between $R O E$ and $E F$. Similar indications also exist for EPS and environmental friendliness, motivating us to explore this exciting nexus further. No multicollinearity issues are apparent in Table 3. Moreover, the study considers VIF (Variance Inflation Factor) measure to address multicollinearity across the regression analysis.

\subsection{Reduction of ecological footprint and financial performance during COVID-19: main hypothesis}

This study focuses on reducing environmental footprints on the performance of U.S. corporations during COVID19. Previous studies concentrate on the ecological factor's effects on accounting-based performance (Kuckertz et al. 2019), governance (Najaf et al. 2021a, b, c), corporate risk-taking (Najaf et al. 2021a, b, c). However, this study twists the direction and assumes that the rise of environmental concern is related to financial performance during the pandemic period. It implies that the firms that implemented the policies of reducing the ecological footprint perform their counterparts during the COVID-19 period.

We believe that the implementation of an ecological footprint leads to better performance. Align with this thought, Table 4 shows the testing result of financial performance (ROA, ROE, EPS) with the interaction variable of $C O V I D * E F$ (Model 1 to 3 ). The interaction variable shows the marginal effect of the corporations with footprint reduction policies versus firms without it. Also, it is worth noting that we associated the environmental implementation at the beginning of the year with the year-end financial performance. This will also address endogeneity, where the lagged value of the $E F$ affects the financial performance and not vice-versa.

With other variables being equal, the $C O V I D * E F$ significantly positively impacted ROA by 0.26 (Model 1). Similar conclusions were obtained using alternative financial performance measurements such as ROE (Model 2) and EPS (Model 3). The results suggested that the firms with ecological footprint reduction policies demonstrate a tendency to have better financial performance, in line with the first hypothesis. In addition, the findings corroborated with prior literature; the firms with environmental performance have likelihoods of success (Kuckertz et al. 2019). Also, our results revealed that the COVID-19 has a negative effect on financial performance, supporting prior literature (Najaf and Chin 2020). In contrast, the $E F$ is positively related to financial performance, which is cited by 


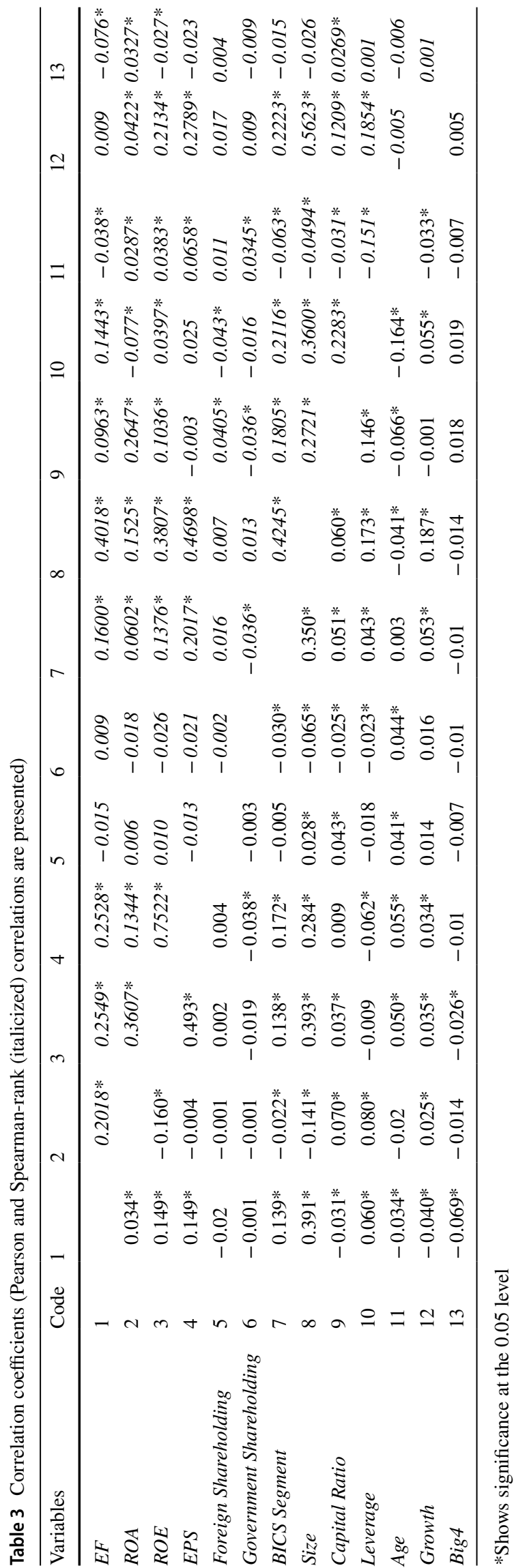

Table 4 Regression analysis of environmental supply chain and performance- main hypothesis

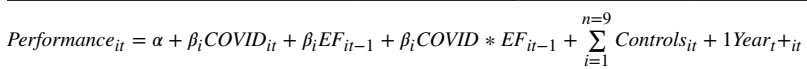

(4)

\begin{tabular}{|c|c|c|c|}
\hline \multirow{3}{*}{$\underline{\text { Variables }}$} & \multicolumn{3}{|c|}{ Financial performance } \\
\hline & \multirow{2}{*}{$\begin{array}{l}\text { ROA } \\
\text { Model } 1\end{array}$} & \multirow{2}{*}{$\begin{array}{l}\text { ROE } \\
\text { Model } 2\end{array}$} & \multirow{2}{*}{$\begin{array}{l}\text { EPS } \\
\text { Model } 3\end{array}$} \\
\hline & & & \\
\hline \multirow[t]{2}{*}{ COVID } & $-0.301 * * *$ & $-5.158 * * *$ & $-0.627 * * *$ \\
\hline & {$[-6.146]$} & {$[-3.472]$} & {$[-3.745]$} \\
\hline \multirow[t]{2}{*}{$E F$} & $0.576 * * *$ & $1.733 *$ & $0.408 * * *$ \\
\hline & {$[9.258]$} & {$[1.801]$} & {$[2.618]$} \\
\hline \multirow[t]{2}{*}{$C O V I D * E F$} & $0.260 *$ & $6.089 * * *$ & $0.637 * *$ \\
\hline & [1.893] & {$[2.732]$} & [1.964] \\
\hline \multirow[t]{2}{*}{ Foreign Shareholding } & $-0.072 * * *$ & -0.459 & $0.259 * * *$ \\
\hline & {$[-5.608]$} & {$[-1.451]$} & {$[3.782]$} \\
\hline \multirow[t]{2}{*}{ Government Shareholding } & $-0.101 * * *$ & $6.564 * * *$ & $0.649 * * *$ \\
\hline & {$[-6.492]$} & [18.332] & [16.996] \\
\hline \multirow[t]{2}{*}{ BICS Segment } & $0.035 * * *$ & 0.151 & -0.002 \\
\hline & {$[5.354]$} & {$[1.454]$} & {$[-0.111]$} \\
\hline \multirow[t]{2}{*}{ Size } & 0.000 & $-0.267 * * *$ & $-0.024 * * *$ \\
\hline & {$[0.343]$} & {$[-8.058]$} & {$[-7.218]$} \\
\hline \multirow[t]{2}{*}{ Capital Ratio } & -0.000 & $0.035 * *$ & $0.009 * * *$ \\
\hline & {$[-0.287]$} & {$[2.544]$} & [4.889] \\
\hline \multirow[t]{2}{*}{ Leverage } & $0.002 * * *$ & $-0.012 * *$ & 0.000 \\
\hline & {$[4.408]$} & {$[-2.115]$} & {$[0.137]$} \\
\hline \multirow[t]{2}{*}{ Age } & 0.035 & $-2.086^{* * *}$ & 0.055 \\
\hline & {$[0.895]$} & {$[-2.743]$} & {$[0.493]$} \\
\hline \multirow[t]{2}{*}{ Growth } & $2.412 * * *$ & $-30.670 * * *$ & $-2.719 * * *$ \\
\hline & {$[23.364]$} & {$[-14.109]$} & {$[-11.122]$} \\
\hline \multirow[t]{2}{*}{ Big4 } & $-0.301 * * *$ & $-5.158 * * *$ & $-0.627 * * *$ \\
\hline & {$[-6.146]$} & {$[-3.472]$} & {$[-3.745]$} \\
\hline \multirow[t]{2}{*}{ Constant } & $0.576^{* * *}$ & $1.733^{*}$ & $0.408 * * *$ \\
\hline & [9.258] & [1.801] & [2.618] \\
\hline SE cluster & Firm & Firm & Firm \\
\hline $\begin{array}{l}\text { Time and industry Fixed } \\
\text { effect }\end{array}$ & Yes & Yes & Yes \\
\hline Observations & 5686 & 5417 & 5742 \\
\hline$R^{2}$ Squared & $12.40 \%$ & $19.19 \%$ & $15.51 \%$ \\
\hline
\end{tabular}

Performance $_{i t}$ is a continuous variable proxied by the ROA, ROE, and EPS of a firm(i) in year (t). COVID $D_{i t}$ is a dummy variable, where COVID period for year $2020=" 1 "$ and "0", otherwise. Also, the $E F$ is dichotomous variable, when a firm(i) implemented any initiatives to reduce the environmental footprint of its supply chain in year (t) then $=" 1 "$, otherwise "0". The Controls $s_{i t}$ is a set of control variables (firm age, firm growth, foreign sharing, Government sharing, BICS segment, Size, Capital Ratio, leverage, Age, Growth, and Big4). Also, we take into account for unknow industry and year fixed effect. The definitions and data sources for the variables are outlined in the Appendix Table 7. The full sample includes 1057 firms from year 2010 until 2020. We allow for clustering of error terms at firm level. The variance inflation factors (VIF) are well below the tolerance level $(\mathrm{VIF}<5)$ and the superscript asterisks $* * *, * *$, and * denote statistical significance at the $1 \%, 5 \%$, and $10 \%$ levels, respectively 
several prior studies extensively (Panayiotopoulos 1996; Sharir and Lerner 2006).

\subsection{Sub-sample analyses}

The results of sub-sample analyses are presented in Table 5 . The sample was categorized into 11 different industrial sectors and tested for the impact of the $C O V I D^{*} E F$ on the firm's financial performance to further support the main hypothesis. With other variables being equal, it was determined that eight out of 11 sectors' $C O V I D^{*} E F$ was positively associated with financial performance. These findings supported the main findings and demonstrated that firms with environmental protection policies performed better than their counterparts during COVID-19.

\subsection{Robustness tests}

The econometric method was changed from pool ordinary least squares (OLS) regression to the quantile regression to support our study hypothesis further. Koenker and Bassett (1978) introduced Quantile regression as a robustness alternative to Ordinary Least Square estimation. Afterwards, this method has been reviewed by Buchinsky (1998); Koenker and Hallock (2001); and Koenker and Ng (2005) followed by the broader application in the finance and banking literature (Schaeck 2008). We apply the quantile regression approach to explain the sensitivity of EF firms' growth in various quantiles to the explanatory variables. The quantile regression model in the framework of Koenker and Bassett (1978) can be written as follows:

$P_{i t}=x_{i t} \beta_{0}+\varepsilon \theta_{i t}$ with Quant ${ }_{\theta}\left(\left(P_{i t} \mid x_{i t}\right)=x_{i t} \beta_{0}\right.$,

where $i$ denotes country, t denotes time, $y_{i t}$ denotes economic development, $x_{i t}^{\prime}$ is a vector of regressors, $\beta$ is the vector of parameters to be estimated, $\varepsilon$ is vector of residuals. Quant $_{\theta}\left(\left(y_{i t} \mid x_{i t}\right)\right.$ denotes $\theta^{\text {th }}$ conditional quantile of $y_{i t}$ given $x_{i t}$. $\theta$ th regression quantile, $0<\theta<1$, solves the following problem:

$\min _{\beta} \frac{1}{n}\left\{\sum_{i, t: P_{i t}>x_{i j}^{\prime} \beta} \theta\left|P_{i t}-x_{i t}^{\prime} \beta\right|+\sum_{i, t: P_{i t}<x_{i t}^{\prime} \beta}(1-\theta)\left|P_{i t}-x_{i t}^{\prime} \beta\right|\right\}=\min _{\beta} \frac{1}{n} \sum_{i=1}^{n} \rho_{\theta} \varepsilon_{\theta i t}$

where $\rho_{\theta}(\cdot)$, which is known as the 'check function', is defined as":

$\rho_{\theta}\left(\varepsilon_{\theta i t}\right)=\left\{\begin{array}{cc}\theta \varepsilon_{\theta i t} & \text { if } \theta \varepsilon_{\theta i t} \geq 0 \\ (\theta-1) \varepsilon_{\theta i t} & \text { if } \theta \varepsilon_{\theta i t} \leq 0\end{array}\right\}$

Finally, Eq. (2) is solved by linear programming methods. According to Buchinsky (1998), as one increases $\theta$ continuously from 0 to 1 , one traces the entire conditional distribution of $P_{i t}$, conditional on $x_{i t}$.

Due to the advantages (as stated above) of quantile regression estimation technique over OLS, fixed and random effect models. The latter aided the discovery of the 25 th quantile $C O V I D * E F$ of a particular probability. For testing purposes, $25 \%, 50 \%, 75 \%$, and $99 \%$ probability were set to determine the quantile relationships for our main hypothesis.

With other variables being equal, it was found that the Environmental protection measures are significant positive with ROA ${ }^{1}$ during the COVID-19 period (Models 1-4). Likewise, the corporations that implemented the reduction of ecological footprint achieved better ROE during the pandemic period than their counterparts (Models 5-8).

\section{Conclusion}

This study examined whether the projects of U.S. corporations have implemented initiatives to reduce the environmental footprint of their supply chain during COVID-19. We expect that the implementation of environmental practices could have an important effect on a firm's financial performance because the profitability could be decreased by high production costs linked to environmental innovation according to neoclassical economic theory as cited by Manrique and Martí-Ballester (2017). Our results based on the regression analysis suggest that firms implementing the initiative to reduce environmental footprint have shown a significant positive financial performance during the COVID-19 period. This indicates the importance of firms focusing on project's initiatives focused on environmental issues. However, firms adopting environmental practices benefit from saving production costs by reducing environmental risks while enhancing their relationship with the key stakeholders, which contributes to achieving competitive advantages and thus improves their corporate financial performance in the long term. Moreover, they are also spurred by the desire to abide by and meet the growing environmental regulations being implemented by the government and other regulatory bodies. This is supported by the adoption of ISO 14001 on international levels, and its effects have been evaluated by several researchers (Aragon-correa 1998; Kleindorfer et al. 2005; Rothenberg et al. 2001). In parallel, the environmental footprint is considered as part of the green management practices, mainly during the COVID-19 period. It is known as ecological footprint considering the entirety of supply and demand of goods and services.

\footnotetext{
1 The Table 6 just show the results of $R O A$ and $R O E$, if anyone need the results of $E P S$, please contact the authors.
} 


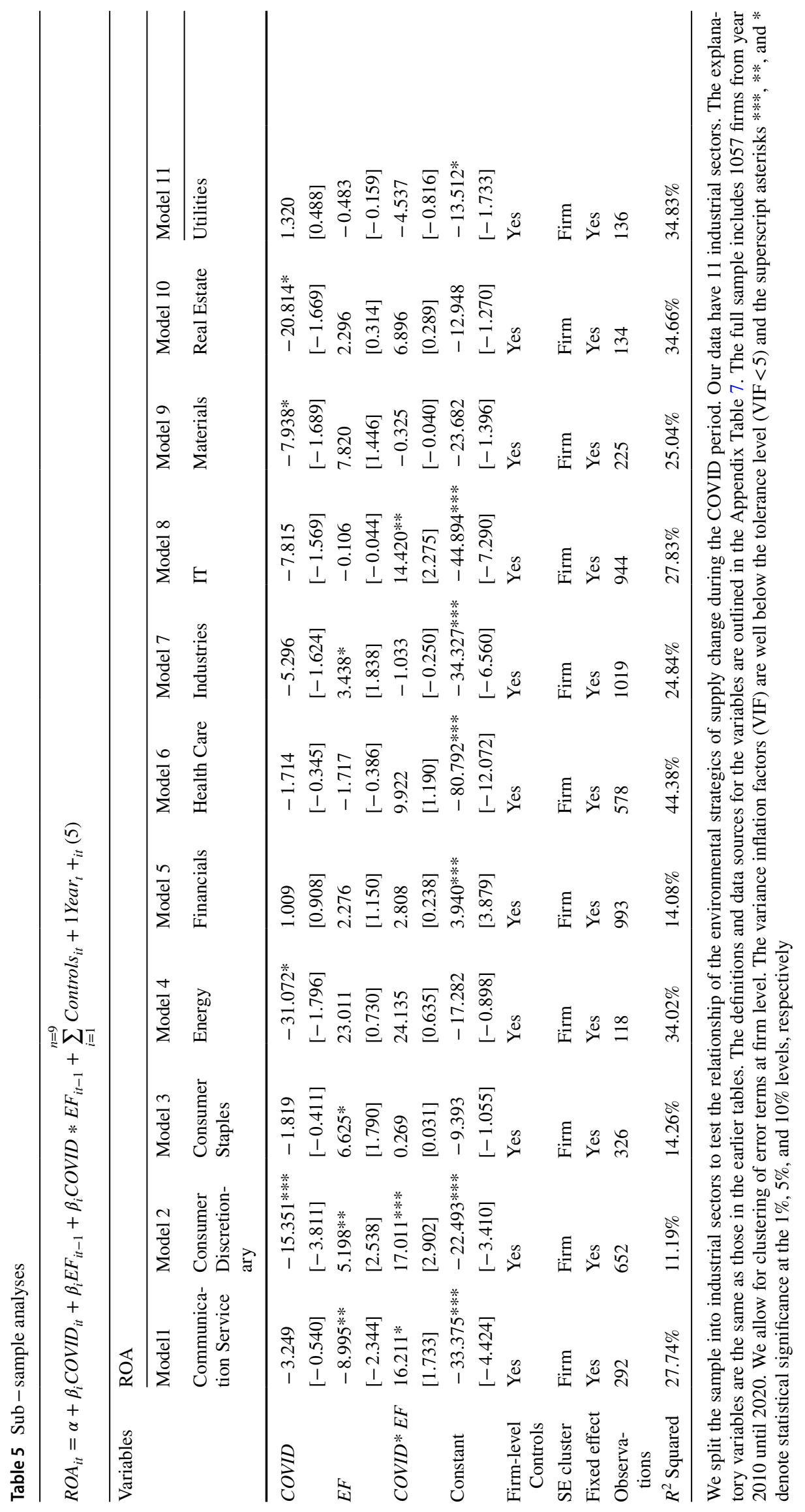


Table 6 Robustness test

$Q_{t}\left(\right.$ Performance $_{i} \mid$ COVID $\left._{E} E F_{i-1}\right)=\alpha(t)+\beta_{1}(t)$ COVID $_{i}+\beta_{2}(t-1) E F+\beta_{3}(t)$ COVID $_{2} E F_{i-1}+\beta_{4}(t) \sum_{i=1}^{n=9}$ Controls $_{i t}+1(t)$ Year $_{t}+2(t)$ Industry $_{i}$ (6)

\begin{tabular}{|c|c|c|c|c|c|c|c|c|}
\hline \multirow[t]{2}{*}{ Variables } & \multicolumn{4}{|l|}{ ROA } & \multicolumn{4}{|l|}{ ROE } \\
\hline & $25 \%$ & $50 \%$ & $75 \%$ & $99 \%$ & $25 \%$ & $50 \%$ & $75 \%$ & $99 \%$ \\
\hline & 1 & 2 & 3 & 4 & 5 & 6 & 7 & 8 \\
\hline \multirow[t]{2}{*}{ COVID } & $-0.059 * * *$ & $-0.194 * * *$ & $-0.234 * *$ & $-2.257 *$ & $-4.177 * * *$ & $-1.365 * *$ & $-2.047 * *$ & $-17.176^{*}$ \\
\hline & {$[-3.923]$} & {$[-4.317]$} & {$[-2.354]$} & {$[-1.849]$} & {$[-3.001]$} & {$[-2.406]$} & {$[-2.522]$} & {$[-1.947]$} \\
\hline \multirow[t]{2}{*}{$E F$} & $0.331 * * *$ & $0.473 * * *$ & $0.773 * * *$ & 1.610 & $2.663 *$ & $3.625 * * *$ & $4.290 * * *$ & 1.854 \\
\hline & [22.125] & [10.543] & [7.781] & [1.321] & [1.914] & [6.392] & {$[5.285]$} & {$[0.210]$} \\
\hline \multirow[t]{2}{*}{ COVID*EF } & $0.117 * * *$ & 0.032 & $3.046 * * *$ & 3.915 & $2.498 * * *$ & 1.086 & $1.867 * * *$ & $15.978 * *$ \\
\hline & {$[3.572]$} & {$[0.325]$} & [2.68] & [1.467] & [4.91] & {$[0.870]$} & {$[2.55]$} & [1.98] \\
\hline \multirow[t]{2}{*}{ Constant } & $0.952 * * *$ & $1.215^{* * *}$ & $2.400 * * *$ & $12.904 * * *$ & $-25.818 * * *$ & $-3.046 * * *$ & 1.547 & $42.996 * * *$ \\
\hline & {$[55.146]$} & {$[23.495]$} & [20.950] & {$[9.177]$} & {$[-15.895]$} & {$[-4.603]$} & {$[1.633]$} & [4.177] \\
\hline Firm-level controls & Yes & Yes & Yes & Yes & Yes & Yes & Yes & Yes \\
\hline SE cluster & Firm & Firm & Firm & Firm & Firm & Firm & Firm & Firm \\
\hline Fixed effect & Yes & Yes & Yes & Yes & Yes & Yes & Yes & Yes \\
\hline Observations & 5686 & 5686 & 5686 & 5686 & 5417 & 5417 & 5417 & 5417 \\
\hline Pseudo $R^{2}$ & $13.42 \%$ & $9.69 \%$ & $9.08 \%$ & $18.82 \%$ & $8.60 \%$ & $13.01 \%$ & $6.19 \%$ & $6.63 \%$ \\
\hline
\end{tabular}

Performance $_{i t}$ is a continuous variable proxied by the ROA and ROE. We apply quantile regression for our both main econometric models. We apply quantile regression tests at the $25 \mathrm{th}, 50 \mathrm{th}, 75 \mathrm{th}$, and $99 \mathrm{th}$ percentiles of the dataset based on our focused variables. The quantile regressions are non-parametric tests that do not rely on the data normality of data assumption. The explanatory variables are the same as those in the earlier tables. The definitions and data sources for the variables are outlined in the Appendix Table 7. The superscript asterisks ***, **, and * denote statistical significance at the $1 \%, 5 \%$, and $10 \%$ levels, respectively

Given the reduction of supply chain Environmental footprints $(\mathrm{EF})$ policies implementation, the moderating model of this study proves that the interaction variable $\left(E F^{*} C O V I D-19\right)$ can be linked serially to obtain the model's expected output. The results, in general, confirm the existence of the supply chain EF initiatives enhance the corporate financial performance, which opens a black box of the relationship between EF and financial performance during the COVID-19 period.

In order to yield a business value, the supply chain EF policies should positively leverage the financial performance. The empirical results of this study support the conclusion that reduction of supply chain EF is an important element for boosting the financial performance during the pandemic period. As widely acknowledged by the literature, this study supports an adverse relationship between the COVID-19 and corporate financial performance.

The policy implications of these findings are several. In the first place, EF disclosures are increasingly being seen through the lens of the sustainability model for future studies. Hence, it should be a priority for facilitating a high and sustainable financial system. Secondly, parallel arguments and discourse need to be made on why most U.S. firms fail to reach the advantage of EF disclosure. Finally, the quality of EF disclosure, which is often seen as the reason for the objective's variation, should be considered by the regulators and policymakers. This study may interest regulators such as the UK sustainability board, institutional project management, and disaster control authorities.

\section{Appendix}

Author contributions All authors have equally contributed to this article.

Funding There was no funding for this research.

Data availability All data are included in the article.

\section{Declarations}

Informed consent We state that this article is not under consideration at any other journal and if it gets accepted, we fully consent in publish in Operations Management Research (OMR) - Springer. 
Table 7 Variable's summary

$\begin{array}{ll}\begin{array}{l}\text { Dependent variables } \\ \text { Variable }\end{array} & \text { Variable } \\ \text { ROA } & \text { Net Profit/Total Assets } \\ R O E & =\text { Net Profit/Total Equity } \\ E P S & \text { Net Profit-Preference Dividend/ Avg. Outstanding Shares } \\ \text { Focus independent variables } & \\ \text { Variable } & \text { Definition } \\ \text { COVID } & \text { It is a dichotomous variable, which indicates the year of COVID-19. Where } \\ & \text { "1" = are COVID period (the year 2020) and "0", otherwise } \\ \text { Indicates whether the company has implemented any initiatives to reduce } & \text { the environmental footprint of its supply chain. Environmental footprint } \\ & \text { reductions could be achieved by reducing waste, by reducing resource } \\ & \text { use, by reducing environmental emissions, by insisting on the introduc- } \\ & \text { tion of environmental management systems etc. in the supply chain. "N" } \\ & \text { indicates that the company has not explicitly disclosed any such efforts in } \\ & \text { its most recent Annual or Company Responsibility reports }\end{array}$

Firm-level control variables

Variable
Foreign Ownership
Government Shareholding
BICS Segment
Firm Size
Capital Ratio
Leverage
Age
Growth
Big4

Fixed effect controls

Variable

Year

Industry

\section{Definition}

The percentage of shares held by the foreigner shareholders. It is dummy variable, where percentage of ownership is more than $0 \%$ then " 1 " otherwise " 0 "

The percentage of shares held by the public institution. It is dummy variable, where percentage of ownership is more than $0 \%$ then " 1 " otherwise "0"

Number of market segments of a business

Numeric variable representing the size of the firm as measured by the logarithm of total assets

The ratio of capital expenditure to total assets

Total Debt/ Total Assets

Numeric variable representing the size of the firm as measured by the logarithm of total assets

Firms' sales growth using total sales denominated in US\$

Dummy variable equal to 1 if the company is audited by 'Big 4' audit firm otherwise "0"

Definition

1 (0) for observations from year $t$ and 0 for other observations

1 (0) if during year $t$, company $i$ operating in industry $j$ and 0 otherwise
Variable
Bloomberg
Bloomberg
Bloomberg

Relevant studies

Najaf et al. (2021a, b, c)

Our study

Relevant studies

Ali et al. (2020)

Borisova et al. (2012)

Tosun (2020)

Tran and Le (2020)

Hassan and Giouvris (2019)

Ali et al. (2020); Faccio et al. (2011)

Dickinson (2011)

Tran and Le (2020)

Hassan et al. (2020)

Relevant studies

Dickinson (2011)

Ali et al. (2014)
Conflict of interest There is no any kind of conflict and competing interests.

\section{References}

Ahmad Z, Hussain S (2001) KLSE Long run overreaction and the Chinese New-Year effect. J Bus Financ Acc 28(1-2):63-105

Ali A, Klasa S, Yeung E (2014) Industry concentration and corporate disclosure policy. J Acc Econ 58(2-3):240-264

Ali SA, Yassin M, AbuRaya R (2020) The impact of firm characteristics on corporate financial performance in emerging markets: evidence from Egypt. IJCRMM 11(4):70-89

Alipour M, Ghanbari M, Jamshidinavid B, Taherabadi A (2019) The relationship between environmental disclosure quality and earnings quality: a panel study of an emerging market. J Asia Bus Stud 13(2):326-347. https://doi.org/10.1108/JABS-03-2018-0084

Alles MG, Gray GL (2020) Will the medium become the message? A framework for understanding the coming automation of the audit process. J Inf Syst 34(2):109-130. https://doi.org/10.2308/ isys-52633

Andries P, Stephan U (2019) Environmental innovation and firm performance: how firm size and motives matter. Sustainability (switzerland) 11(13):1-17. https://doi.org/10.3390/su11133585

Aragon-correa JA (1998) Strategic proactivity and firm approach to the natural environment. Acad Manag J 41(5):556-567

Banihashemi S, Hosseini MR, Golizadeh H, Sankaran S (2017) Critical success factors (CSFs) for integration of sustainability into construction project management practices in developing countries. Int J Project Manag 35(6):1103-1119. https://doi.org/10.1016/j. ijproman.2017.01.014 
Borisova G, Brockman P, Salas JM, Zagorchev A (2012) Government ownership and corporate governance: evidence from the EU. J Bank Financ 36(11):2917-2934

Bowman AOM, McKenzie JH (2020) Managing a pandemic at a less than global scale: governors take the lead. Am Rev Public Admin. https://doi.org/10.1177/0275074020941700

Buchinsky M (1998) Recent advances in quantile regression models: a practical guideline for empirical research. J Hum Resour 33:88-126

Chell E, Spence LJ, Perrini F, Harris JD (2016) Social Entrepreneurship and Business Ethics: Does Social Equal Ethical? J Bus Ethics 133(4):619-625. https://doi.org/10.1007/s10551-014-2439-6

Chofreh AG, Goni FA, Malik MN, Khan HH, Klemeš JJ (2019) The imperative and research directions of sustainable project management. J Clean Prod. https://doi.org/10.1016/j.jclepro.2019.117810

Czerny Achim I, Xiaowen Fu, Lei Zheng, Oum Tae H (2021) Post pandemic aviation market recovery: Experience and lessons from China. Journal of Air Transport Management 90:101971

Dangelico RM, Nonino F (2019) Sustainable project management: a conceptualization-oriented review and a framework proposal for future studies. Sustainability 11(9):2664. https://doi.org/10.3390/ su11092664

Dickinson V (2011) Cash flow patterns as a proxy for firm life cycle. Account Rev 86(6):1969-1994

Dranev Y, Izosimova A, Meissner D (2020) Organizational ambidexterity and performance: assessment approaches and empirical evidence. Journal of the Knowledge Economy 11(2):676-691. https:// doi.org/10.1007/s13132-018-0560-y

Dwiarti R, Hazmi S, Santosa A, Rahman Z (2021) Does bankruptcy matter in non-banking financial sector companies?: evidence from Indonesia. Journal of Asian Finance, Economics and Business 8(3): 441-449. https://doi.org/10.13106/jafeb.2021.vol8.no3.0441

Eccles RG, Ioannou I, Serafeim G (2014) the Impact of corporate sustainability on organizational processes. Nber Working Paper Series 1-35. https://doi.org/10.1007/s13398-014-0173-7.2

Edum-Fotwe FT, Price ADF (2009) A social ontology for appraising sustainability of construction projects and developments. Int $\mathbf{J}$ Project Manag 27(4):313-322. https://doi.org/10.1016/j.ijproman. 2008.04.003

Elnahass M, Trinh VQ, Li T (2021) Global banking stability in the shadow of Covid-19 outbreak. Journal of International Financial Markets, Institutions and Money 72(5):101322. https://doi.org/10. 1016/j.intfin.2021.101322

Escobar LE, Molina-Cruz A, Barillas-Mury C (2020) Erratum: BCG vaccine protection from severe coronavirus disease 2019 (COVID19) (Proc Natl Acad Sci 117 (17720-17726). Proc Natl Acad Sci USA 117(44):27741-27742. https://doi.org/10.1073/pnas.20194 38117

Faccio M, Mura R (2011) Large shareholder diversification and corporate risk-taking author (s): Mara Faccio, Maria-Teresa Marchica and Roberto Mura Published by: Oxford University Press. Sponsor: The society for financial studies. Stable. The Review of Financial Studies 24(11):3601-3641. https://doi.org/10.1093/rfs/hhr065

Freeman RE (2010) Strategic management: A stakeholder approach. Cambridge University Press

Freudenreich B, Lüdeke-Freund F, Schaltegger S (2020) A stakeholder theory perspective on business models: Value creation for sustainability. J Bus Ethics 166(1):3-18

Gareis R (2013) Re-thinking project initiation and project management by considering principles of sustainable development. In Sustainability Integration for Effective Project Management (129-143). IGI Global. https://doi.org/10.4018/978-1-4666-4177-8.ch008

Gimenez C, Sierra V, Rodon J (2012) Sustainable operations: their impact on the triple bottom line. Int J Prod Econ 140(1):149-159. https://doi.org/10.1016/j.ijpe.2012.01.035
Grougiou V, Leventis S, Dedoulis E, Owusu-Ansah S (2014) Corporate social responsibility and earnings management in U.S. banks. Accounting Forum 38(3):155-169. https://doi.org/10.1016/j.accfor.2014.05.003

Ionescu B, Müller H, Péteri R, Dang-Nguyen DT, Piras L, Riegler M, ... Karampidis K (2019) ImageCLEF 2019: Multimedia retrieval in lifelogging, medical, nature, and security applications. Lecture Notes in Computer Science (Including Subseries Lecture Notes in Artificial Intelligence and Lecture Notes in Bioinformatics) 11438 LNCS(i),301-308. https://doi.org/10.1007/978-3-030-15719-7_40

Hassan M, Giouvris E (2019) Financial institutions mergers: a strategy choice of wealth maximization and economic value. J Financ Econ Policy 12:495

HassanOMER WK, Aljaaidi KS, Habtoor OS (2020) Board quality, audit quality and economic firm value: the case of manufactured Saudi's listed companies. Quality-Access to Success 21(178)

Hussain M, Khan M, Al-Aomar R (2016) A framework for supply chain sustainability in service industry with confirmatory factor analysis. Renew Sustain Energy Rev 55:1301-1312. https://doi. org/10.1016/j.rser.2015.07.097

Huynh TLD (2020) When 'green' challenges 'prime': empirical evidence from government bond markets. J Sustain Financ Invest. https://doi.org/10.1080/20430795.2020.1769984

Hwang BG, Ng WJ (2013) Project management knowledge and skills for green construction: overcoming challenges. Int J Project Manag 31(2):272-284. https://doi.org/10.1016/j.ijproman.2012. 05.004

Jensen O, Tesche CD (2002) Short communication Frontal theta activity in human increases with memory load in a working memory task. Eur J Neurosci 15: 5

Kleindorfer PR, Singhal K, Van Wassenhove LN (2005) Sustainable operations management. Prod Oper Manag 14(4):482-492. https:// doi.org/10.1111/j.1937-5956.2005.tb00235.x

Koenker R, Bassett G Jr (1978) Regression quantiles. Econometrica 46:33-50

Koenker R, Hallock KF (2001) Quantile regression. J Econ Perspect 15(4):143-156

Koenker R, Ng P (2005) Inequality constrained quantile regression. Sankhyā 67:418-440

Kuckertz A, Berger ESC, Gaudig A (2019) Responding to the greatest challenges? Value creation in ecological startups. J Clean Prod 230:1138-1147. https://doi.org/10.1016/j.jclepro.2019.05.149

Kuckertz A, Berger ESC, Prochotta A (2020) Misperception of entrepreneurship and its consequences for the perception of entrepreneurial failure-the German case. Int J Entrep Behav Res 26(8):1865-1885. https://doi.org/10.1108/JJEBR-02-2020-0060

Linton JD, Klassen R, Jayaraman V (2007) Sustainable supply chains: an introduction. J Oper Manag 25(6):1075-1082. https://doi.org/ 10.1016/j.jom.2007.01.012

Manrique S, Martí-Ballester C-P (2017) Analyzing the effect of corporate environmental performance on corporate financial performance in developed and developing countries. Sustainability 9(11):1957

Marcelino-Sádaba S, González-Jaen LF, Pérez-Ezcurdia A (2015) Using project management as a way to sustainability. from a comprehensive review to a framework definition. J Clean Prod 99:1-16. https://doi.org/10.1016/j.jclepro.2015.03.020

Martens ML, Carvalho MM (2016) The challenge of introducing sustainability into project management function: multiple-case studies. J Clean Prod 117:29-40. https://doi.org/10.1016/j.jclep ro.2015.12.039

Michaelides R, Bryde D, Ohaeri U (2014) Sustainability from a project management perspective are oil and gas supply chains ready to. In: Project management institute research and education conference (July 2014), pp 1-17 
Najaf K, Chin A (2020) The impact of the China Stock market on global financial markets during COVID-19. Int J Public Sector Performance Management (IJPSPM)

Najaf K, Chin A, Najaf R (2021) Conceptualizing the corporate governance issues of fintech firms. The fourth industrial revolution: implementation of artificial intelligence for growing business success, pp 187-197

Najaf K, Liew CY, Schinckus C (2020) VaR and market value of fintech companies: an analysis and evidence from global data. J Manag Financ

Najaf K, Mostafiz MI, Najaf R (2021b) Fintech firms and banks sustainability: why cybersecurity risk matters? Int J Financ Eng 08:2150019

Najaf K, Subramaniam RK, Atayah OF (2021c) Understanding the implications of FinTech Peer-to-Peer (P2P) lending during the COVID-19 pandemic. J Sustain Financ Invest. https://doi.org/10. 1080/20430795.2021.1917225

Najaf R, Najaf K (2021) Nexus of political connections with green finance and financial performance. J Environ Treat Tech 9(1):305-309

Neeveditah P-M, Karishma A, Nitoosheeka Devi R (2017) Environmental management systems and financial performance: the case of listed companies in Mauritius. Theor Econ Lett 07(07):2054 2069. https://doi.org/10.4236/tel.2017.77139

Panayiotopoulos PI (1996) Challenging orthodoxies: cypriot entrepreneurs in the London garment industry. New Community 22(3):437-460

Polishchuk Y, Kornyliuk A, Lopashchuk I, Pinchuk A (2020) SMEs debt financing in the EU: On the eve of the coronacrisis. Banks and Bank Systems 15(3):81-94. https://doi.org/10.21511/bbs. 15(3).2020.08

Qiu R, Hou S, Chen X, Meng Z (2021) Green aviation industry sustainable development towards an integrated support system. Bus Strateg Environ. https://doi.org/10.1002/bse.2756

Queiroz MM, Ivanov D, Dolgui A, Fosso Wamba S (2020) Impacts of epidemic outbreaks on supply chains: mapping a research agenda amid the COVID-19 pandemic through a structured literature review. Ann Oper Res. https://doi.org/10.1007/ s10479-020-03685-7

Rababah A, Al-Haddad L, Sial MS, Chunmei Z, Cherian J (2020) Analyzing the effects of COVID-19 pandemic on the financial performance of Chinese listed companies. J Public Aff. https:// doi.org/10.1002/pa.2440

Robichaud LB, Anantatmula VS (2011) Greening project management practices for sustainable construction. J Manag Eng 27(1):48-57. https://doi.org/10.1061/(asce)me.1943-5479.0000030

Rothenberg S, Pil FK, Maxwell J (2001) Lean, green, and the quest for superior environmental performance. Prod Oper Manag 10(3):228-243. https://doi.org/10.1111/j.1937-5956.2001.tb003 72. $\mathrm{x}$

Sánchez MA (2015) Integrating sustainability issues into project management. J Clean Prod 96(96):319-330. https://doi.org/10.1016/j. jclepro.2013.12.087

Schaeck K (2008) Bank liability structure, FDIC loss, and time to failure: a quantile regression approach. J Financ Serv Res 33(3): $163-179$

Schmidt AB (2020) Optimal ESG portfolios: an example for the Dow Jones Index. J Sustain Financ Invest. https://doi.org/10.1080/ 20430795.2020.1783180

Seuring S (2013) A review of modeling approaches for sustainable supply chain management. Decis Support Syst 54(4):1513-1520. https://doi.org/10.1016/j.dss.2012.05.053

Sharir M, Lerner M (2006) Gauging the success of social ventures initiated by individual social entrepreneurs. J World Bus 41(1):6-20. https://doi.org/10.1016/j.jwb.2005.09.004
Shen H, Fu M, Pan H, Yu Z, Chen Y (2020) The impact of the COVID19 pandemic on firm performance. Emerg Mark Financ Trade 56(10):2213-2230. https://doi.org/10.1080/1540496X.2020.1785863

Shin JY, Hyun J, Oh S, Yang H (2018) The effects of politically connected outside directors on firm performance: evidence from Korean chaebol firms. Corp Govern 26(1):23-44

Silvius AJG, Schipper R, Planko J, van den Brink J, Köhler A (2012) Sustainability in project management. Gower Publishing, Farnham

Silvius G (2013) Sustainability in project management processes. Sustain Integr Effect Project Manag. https://doi.org/10.4018/978-14666-4177-8.ch004

Silvius G (2017) Sustainability as a new school of thought in project management. J Clean Prod 166:1479-1493. https://doi.org/10. 1016/j.jclepro.2017.08.121

Song L, Zhou Y (2020) The COVID-19 pandemic and its impact on the global economy: what does it take to turn crisis into opportunity? Chin World Econ 28(4):1-25. https://doi.org/10.1111/cwe.12349

Sroufe R, Gopalakrishna-Remani V (2019) Management, social sustainability, reputation, and financial performance relationships: an empirical examination of US firms. Organization \& Environment 32(3):331-362. Journal : Large 12063 Article No : 206 Pages: 1 MS Code: 206 Dispatch: 31-8-2021

Tingström J, Swanström L, Karlsson R (2006) Sustainability management in product development projects - the ABB experience. J Clean Prod 14(15-16):1377-1385. https://doi.org/10.1016/j.jclepro.2005.11.027

Toljaga-Nikolić D, Todorović M, Dobrota M, Obradović T, Obradović V (2020) Project management and sustainability: playing trick or treat with the planet. Sustainability (switzerland) 12(20):1-20. https://doi.org/10.3390/su12208619

Tosun OK (2020) Changes in corporate governance: externally dictated vs voluntarily determined. Int Rev Financ Anal 101608

Tran NH, Le CD (2020) Ownership concentration, corporate risktaking and performance: evidence from Vietnamese listed firms. Cogent Econ Financ 8(1): 1732640

Valdes-Vasquez R, Klotz LE (2013) Social sustainability considerations during planning and design: framework of processes for construction projects. J Constr Eng Manag 139(1):80-89. https://doi.org/ $10.1061 /$ (asce)co.1943-7862.0000566

Vogel HL (2020) Entertainment industry economics: A guide for financial analysis. Cambridge University Press

Wong CWY, Wong CY, Boon-itt S (2018) How does sustainable development of supply chains make firms lean, green and profitable? A resource orchestration perspective. In Business Strategy and the Environment 27. https://doi.org/10.1002/bse.2004

Zamojska A, Próchniak J (2017) Measuring the social impact of infrastructure projects: the case of Gdańsk International Fair Co. JEMI 13(2017):25-42. https://doi.org/10.7341/20171342

Zgheib E, Bechaux C, Crepet A, Mombelli E, Bois FY (2017) Highthroughput methods for toxicology and health risk assessment. Environ Risques Et Sante 16(1):44-58. https://doi.org/10.1684/ ers.2016.0943

Zoğal V, Domènech A Emekli G (2020) Stay at (which) home: second homes during and after the COVID- 19 pandemic. Journal of Tourism Futures Vol. ahead-of-print No. ahead-of-print. https:// doi.org/10.1108/JTF-06-2020-0090

Publisher's note Springer Nature remains neutral with regard to jurisdictional claims in published maps and institutional affiliations. 